\title{
Pre-Cretaceous Intraplate Basins of NE Africa
}

\author{
by Heinz Schandelmeier
}

For some years now West German scientists have been carrying out a major research project in northeastern Africa, the broad outlines of which were explained earlier by E. Klitzsch (Episodes, September 1983). The present article sets out a dynamic interpretation of basin development and discusses the Phanerozoic intraplate deformation that led, in Egypt and northern Sudan, to the formation of a system of basins and uplifts controlled by pre-existing basement structures. Regional extension, stresses along plate boundaries, and magmatism all played a role in the development of the region. (Ed.)

\section{Introduction}

Since Early Cambrian times, immediately following the Pan-African orogeny, the northeastern African continental plate has been subjected to various episodes of intracontinental deformation. As a result of intraplate tectonism and lateral stresses associated with vertical movements, a system of partly interconnected basins with intervening uplifts was created, a feature in common with many continental regions (Park, 1988).

The formation of intraplate basins is closely related to pre-existing structures in the crust on which such basins were formed (e.g. Bally, 1980). For example, it can be clearly demonstrated for Egypt and northern Sudan that reactivation of Precambrian structures was one of the important mechanisms contributing to the initiation of basin formation (Schandelmeier et al., 1987). The various reasons for vertical movements in northeastern Africa are still much debated, but it seems clear that lateral extension, variations in plate boundary stresses, and intraplate magmatic activity all contributed to the complex Phanerozoic history of this region.

\section{Basin Configurations}

Two major types of pre-Cretaceous basins can be recognized in northeastern Africa. The first group includes the Erdis, Kufra and Dakhla basins (Fig. 1), which are more than $300 \mathrm{~km}$ wide and contain over $3000 \mathrm{~m}$ of continental and marine sediments. The oldest sediments in these basins are of Cambrian age.

The second type of basins are rarely reeper than $500 \mathrm{~m}$ (Fig. 1). In northern Sudan and probably in the Erdis Basin, the stratioraphic record hegins with Permian to Lower Jurassic continental sedjments north of Wadi Howar, followed by Cretaceous and partly Tertiary strata (Abyad Basin). South of Wadi Howar in northern Sudan only sediments of Cretaceous age are recorded (Klitzsch and Wycisk, 1987). In the Southwestern Desert of Egypt the record hegins with Upper Jurassic sediments, whereas in southeastern and eastern Epypt Upper Cretaceous sediments rest unconformably on the basement.

Sediments of late Mesozoic age, which reach a thickness of more than $1500 \mathrm{~m}$, are also exposed in the deeper basins. This confirms that subsidence was much more extensive there than in southern and eastern Egypt. However, Cretaceous sedimentation over the whole area seems, in particular, to be related more to large-scale epeirogenic crustal warping at high sea-level stand, and less to lithospheric extensional processes (Klitzsch and Wycisk, 1987; Hendriks,
I987; Wycisk, 1987). These basins are for this reason not considered in the context of this paper, which is concerned only with the pre-Cretaceous basins.

\section{Tectonic Subsidence of the Paleozoic Basins}

The process of upper crustal faulting in the Kufra, Erdis and Dakhla basins is not fully understoor, because of the lack of high quality seismic reflection profiles. However, the few available studies of seismic profiles, aeromagnetic and drillhole data (CONOCO, unpublished reports), together with detailed geological surface information (Klitzsch, 1970, 1981; Klitzsch and Wycisk, 1987) have revealed two major facts. First, the morphological expression of the basin depocenters, as seen by the basement contour lines (Fig. 2; Thorweihe, 1988), is rather concentric. Second, the faults are generally steep, non-rotational, and normal. Faults, sediments and basement are tilted in the same direction towards basin centers. According to Artyushkov (1987) these basins can be classified as S-type basins; Gibbs (1987) refers to them as "sag basins."

The elongated, narrow depocenters of these basins are aligned along a roughly $\mathrm{N} 35^{\circ} \mathrm{E}$-trending megashear zone of late Pan African age, known as the Trans-Africa Lineament

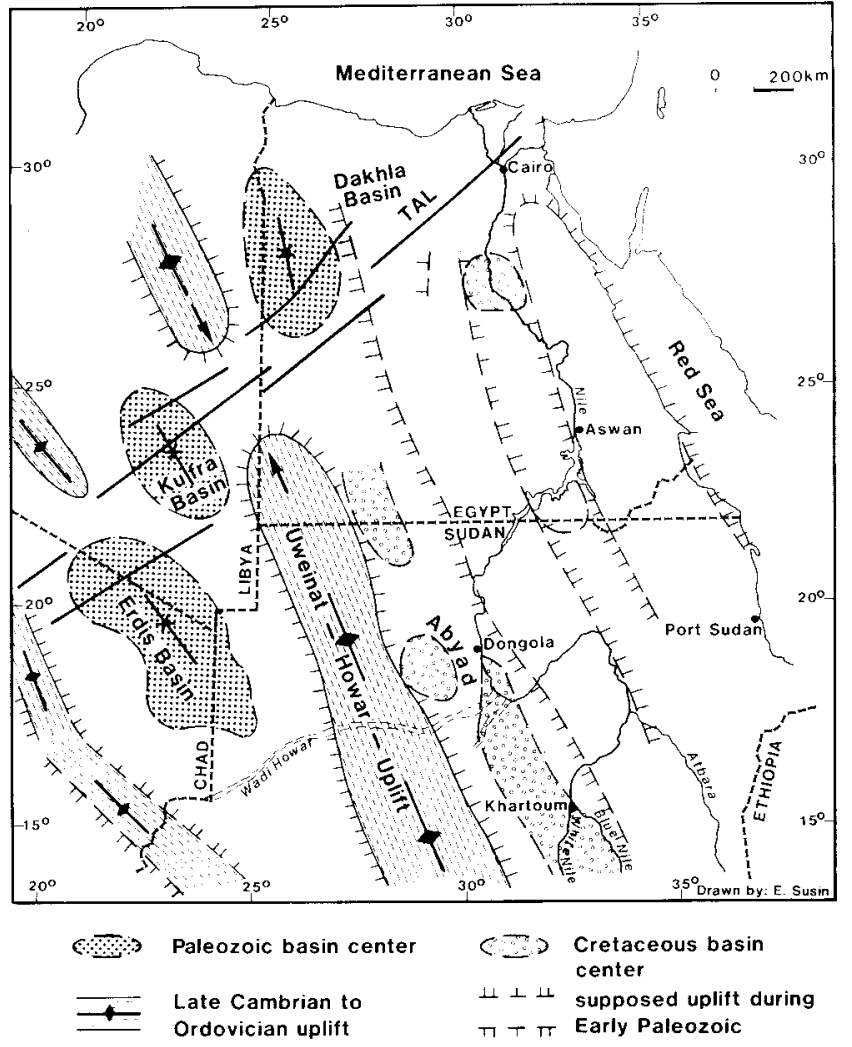

Figure 1: Early Paleozoic structural grain of northeastern Africa and its possible reactivation during late Mesozoic time. TAL: Trans-Africa Lineament. After Schandelmeier and others (1987). 
(Fig. 1; Nagy et al., 1976). To the northeast this lineament extends into the Bahariya uplift of northern Egypt, and to the southwest it continues via the Lake Chad depression into the Benue Trough of Nigeria. The lineament is probably one of the continental extensions of the equatorial transform fault system of the Atlantic (Browne and Fairhead, 1983).

With a few exceptions, early Paleozoic sedimentation in northeastern Africa is confined to an area west of the Uweinat-Howar uplift and to the Dakhla basin (Fig. 1). To the east of this uplift Paleozoic sediments occur only as scattered remnants; they are thus only of limited use for paleogeographic reconstructions.

The Paleozoic depocenters are separated by intrabasinal ridges and contain more than $1000 \mathrm{~m}$ of fluvio-continental and minor marine Cambrian sediments. However, some distance from both sides of the Trans-Africa lineament, Cambrian sedimentation is controlled by a NNW-SSE structural grain. Klitzseh (1981) and Klitzseh and Wycisk (1987) have shown that the uplift systems in Figure 1 are unconformably overlain by marine Silurian strata, whereas in the adjacent depressions several hundreds of metres of Cambrian and Ordovician sediments were accumulated. Cambrian sedimentation in these grabens was generally syntectonic (Klitzsch, 1970), and the NNW-SSE striking faults are normal, with most dips over $60^{\circ}$.

\section{A Model for the S-Basins}

The contrast in structural control between the depocenters and the wider basins can be reconciled in terms of a twostage structural history for the basin development (Fig. 3). The Trans-Africa Linerment originated in the late Pan African as a dextral megashear due to horizontal compression from the east and west. This stress field was induced by plate boundary forces that acted during the post-closure accretional stage of the Pan-African Tuareg Shield to the west (Kröner, 1979; Black, 1984). Along the megashear zone a series of narrow, elongated pull-apart basins was formed, into which the earliest Cambrian sediments were deposited.

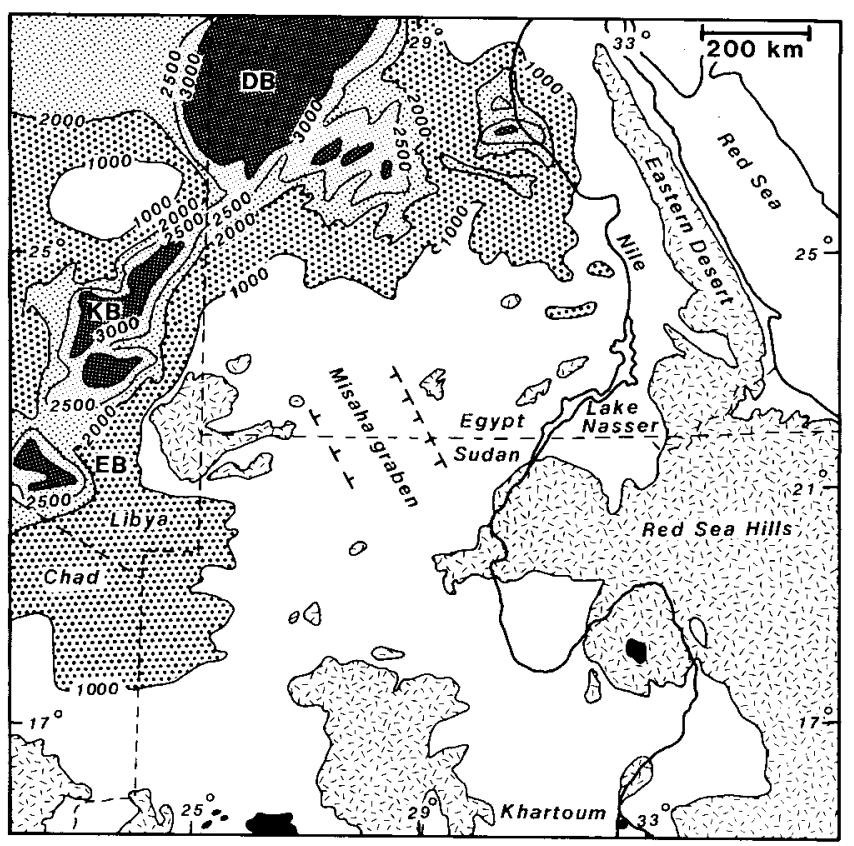

Figure 2: Depth to basement contours in metres below sea level (highlighted by dot patterns) for the Dakhla (DB), Kufra (KB) and Erdis (EB) basins. Random dashes: basement exposed at surface. Solid black: Tertiary alkali-basalts. Blank areas: depth to basement less than $1000 \mathrm{~m}$. After Thorweihe (1988).

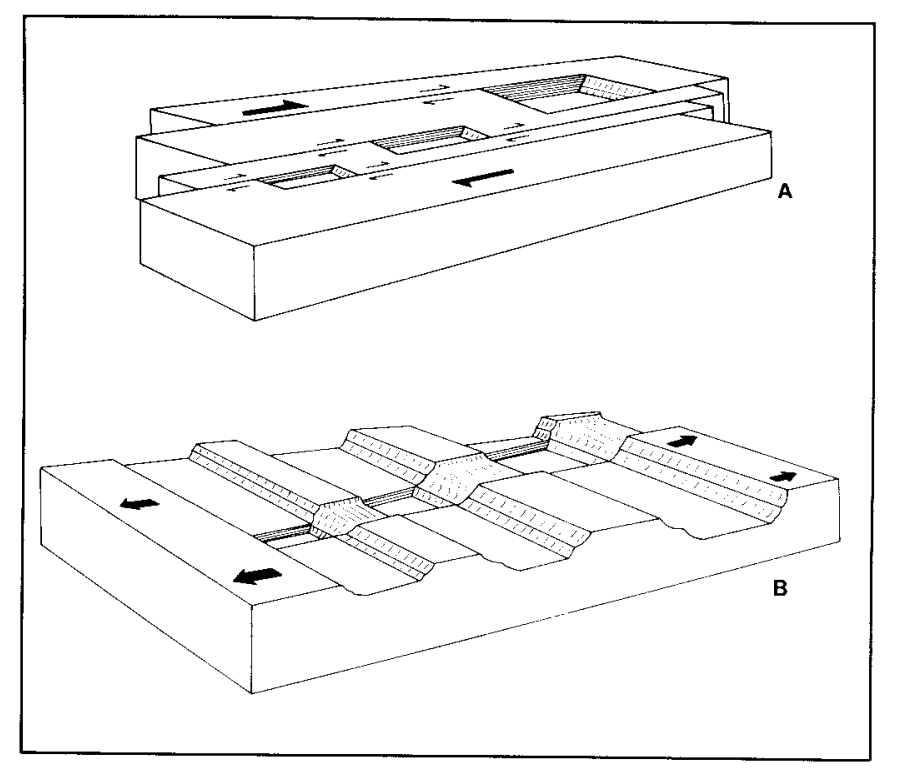

Figure 3: Structural development of northeastern African basins. A: Late Pan-African pull-apart basins along the dextral Trans-Africa Lineament. $B$ : NNW-SSE horsts and grabens related to ENE-WSW tension during Middle to Late Cambrian times. Pre-existing pull-apart basins were integrated to form the depocenters of the newly developing basins.

During the Early Cambrian, the Pan-African orogeny waned, and the northeast shearing eame to halt. Around mid-Cambrian times, a new regional stress field directed to the ENE and WSW was induced, leading to the formation of wide, NNW-SSE-striking horst and graben structures. Syntectonic Cambrian sediments accumulated in the depressions, and the older and kinematically inactive pull-apart basins became the depocenters of a second extensive basin system.

Marine intercalations within the syntectonic Cambrian sediments suggest that the elevation of the area was close to sea level. The shallow marine sedimentation that characterized the Ordovician Period indicates that nearequilibrium conditions between subsidence and sedimentation was achiever at least by the end of Cambrian time.

The Dakhla, Kufra and Erdis basins are characterized by very limited extension of their floors in post-Early Cambrian times, indicating that subsidence was mainly a function of vertical movements. This, however, raises serious questions about the causal mechanisms for basin initiation. The simple stretching model of McKenzie (1978) predicts subsidence in an upper crust of normal thickness for simple reasons of isostatic balance, but it cannot be applied for S-type basins (see Artyushkov, 1987). The low-angle detachment lithosphere model proposed by Wernicke (1985) for the Basin and Range Province of the western United States seems to be inapplicable because of the extreme symmetry of basin morphology in the northeast African basins.

Keen (1987) has convineingly demonstrated that dynamic flow in the lower lithosphere and asthenosphere, as well as partial melting, both occurring during stretching, can produce uplift - quite in contrast to the simple stretching model predictions. A critical extensional factor of $B=1.63$ (where $B$ is a measure of relative extension) is needed to trigger the onset of adiabatic partial melting in the rising asthenosphere. Since stretching in the Kufra Basin was practically negligible, partial melting of the asthenosphere probably did not play a major role in its formation. A thinning of the lower lithosphere through diapiric rise of the asthenosphere, under the assumption of virtually no stretching of the crust, will necessarily cause uplift, as demon- 
strated for example for the Darfur Block in western Sudan (Rermingham et al., 1983) and for the Kenya dome (Browne and Fairhead, 1983).

Subsidence in wide S-type basins, which develop without notable extension of their floors, must necessarily be generated by a process that removes material from the lower lithosphere and which, at the same time, does not stretch the upper crust. Such controlling mechanisms and their causes have yet to be discovered for the basins described here; to do so will probably require regional, deep reflection seismic studies. This is probably the crucial factor why dynamic models for intraplate "sag basins" from Africa are at the moment virtually non-existent. What can be said at present is that causal mechanisms for basin development of the Kufra, Erdis and Dakhla basins have to be sought in lower lithospheric and asthenospheric dynamics, but that stretching of the whole lithosphere was of minor importance.
Carboniferous Period was the reorganization of the intraplate structural pattern of northeastern Africa. The approximately NW-SE directed stress field led to the reactivation as dextral shears of the east-west to NE-SW faults, which had been generated earlier during the Pan-African compression (Schandelmeier et al., 1987).

Naturally, this phenomenon occurred earlier and was more intensive near the collision front, as documented by extensive thrusting, folding and shearing in the Variscan fold belt of $N$ W Africa (Fig. 5). The Early Permian age of the Tadhak

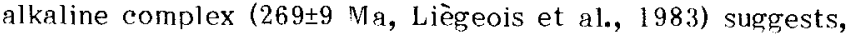
that uplift in the Adrar des Iforas here occurred directly after the initial collision. In northeast Africa, however, the oldest known alkaline ring complex in the Nuba Mountains of Central Sudan yielded a Late Permian $\mathrm{Rb} / \mathrm{Sr}$ whole rock age of $251 \pm 7 \mathrm{Ma}$ (Curtis and Lenz, 1985), while the majority of alkaline ring complexes that are relater to this geotectonic cycle are of Triassic age (Schandelmeier, 1988).

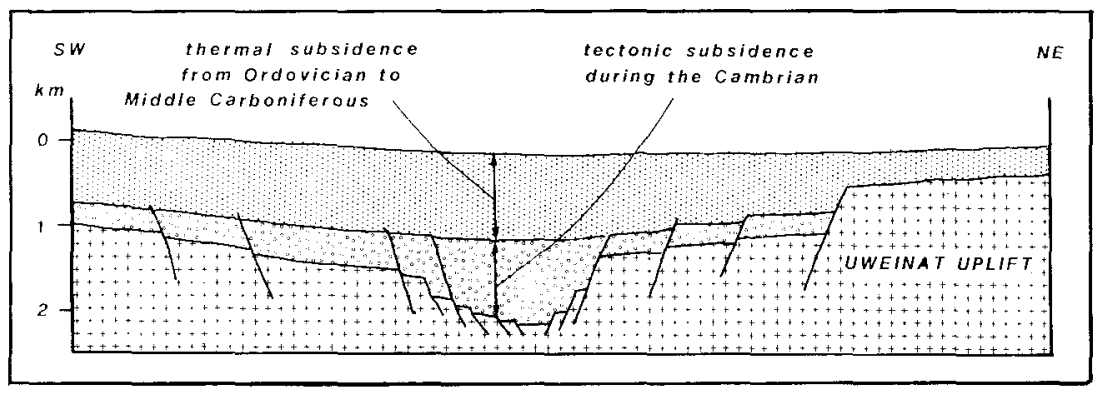

Figure 4: Schematic section through the Erdis Basin to illustrate its two-stage subsidence history. Crosses: Precambrian basement; open circles: Cambrian syntectonic sediments; Stipple: ordovician to Lower Carboniferous cratonic sheet sandstones. Basin width is approximately $300 \mathrm{~km}$.

\section{Thermal Subsidence}

Possibly from Ordovician times onwards and definitely from the beginning of the Silurian Period, the formation of horst and graben structures ceased, and the lithosphere began to return to its initial thickness by cooling (Fig. 4). Silurian sedimentation in both basins and flanking uplifts was generally characterized by vertical and lateral facies stability, indicating deposition under nontectonic conditions. Wycisk (1987) used the term "cratonic sheet sandstones" to characterize the Silurian to Early Carboniferous strata in the northern and eqstern Uweinat region in Egypt. Subsidence continued in the basins, but there is little evidence that this was associated with widespread normal faulting.

The return to normal thickness of the lithosphere can be estimated using the time constant for thermal cooling of about $63 \mathrm{Ma}$, after which $63 \%$ of the total value of elevation change is reached, according to Parsons and Sclater (1977). This means that about $96 \frac{\circ}{\circ}$ of the total elevation change due to thermal cooling of the asthenosphere should have taken place by about $180 \mathrm{Ma}$ after stretching of the lower lithosphere has ceased. If we assume that thermal cooling in the Kufra Basin began in the Ordovician, it should have reached its maximum approximately in Middle Carboniferous time.

Paleozoic sedimentation in the Kufra, Erdis and Dakhla basins did, indeed, cease in the Middle to Late Carboniferous Period, indicating that subsidence came to a halt at that time. However, more detailed investigations have to be carried out to unravel the complex relationship between subsidence history and sedimentation processes in these basins during Paleozoic time.

\section{A Continental Sedimentary Trap}

One of the major consequences of the (Variscan) collision of Gondwana with the northern continents during the Late
Intraplate magmatic activity, which often leads to the formation of anorogenic ring complexes, is known to have its source in the mantle (Bonin, 1986). Asthenospheric rise is often triggered by shearing of the whole lithosphere and related pressure release (Giret and Lameyre, 1985). It seems reasonable, therefore, to relate the regional shearing in northeast Africa to plate boundary forces that were generated during the Variscan collision, in such a way that the effects of the collision appeared later in northeastern than in northwestern Africa. Fault-bounded uplift of east-west blocks is indicated in southern Egypt by the occurrence of

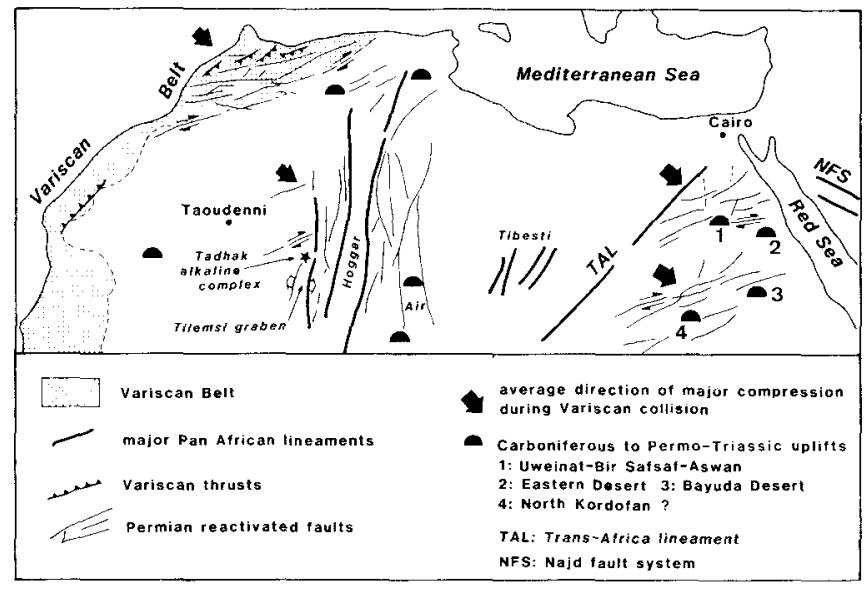

Figure 5: Sketch showing some of the consequences for North Africa of the Variscan collision of Gondwana with the northern continents (for details see text). Data from Liègeois and others (1983) and schandelmeier (1988). 


\section{References}

Artvushkov, F.V., 1987. Rifts and grabens. Tectonophvsies, 133, no. 3-4, p. $32 \mid-331$.

Bally, A.W., 1980, Basins and subsidence - a summary. In: Bally, A.W.. Bender, P.L., Weretehin, 'l'.R. and Waleott, R.l. (ens.), Dynamies of Plate Interiors. American Ceophysical Union, Cieological Soeiety of America, (ieorfynamies Series, v. I, D. $5-20$.

Hermingham, P.M., Fairhead, J.D, and Stuart, Giv., 1983. Ciravity study of the Central Afriogn Rift Sustem: 1 model of continental disruption, 2. The Darfur Central African Rift Sustem: a model of continental disruption, 2. The Darfur domal uplift

Black, R. 1984. The Pan-African event in the geological frainework of Africa. Pangea, v. 2, p. 6-16.

Bonin, R., 1986̈. Ring complex oranites and anorogenic magmatism. IIsevier, New York, $189 \mathrm{p}$.

Browne, S.F. and Fairhead, J.J., 1983. Cravity study of the Central Qfriean Rift system: A model of continential dispuption. I. The Ngaundere and Abu Gabra Rifts. Tectonophysies, v. 94, no. 1-4, p. 187-203.

Curtis, P. and lenz, II, 1985. Ceological and geochronological investigations of selected gikgli ignoous complexes in the Nuba Vourtains, Southern Kordofan, Sudan. Geolorisehes Jarbuch, Reihe 1), $\therefore$. D69, p. 3-24.

Franz, (i., Puchelt, If. and Pastcels, P., 1987. Petrology, geochemistry and age rolations of Triassie and Tertiary voleanic rocks from SW Egynt and NW Suchn. Journal of African Farth Seience, v. 6, no. 3, p, 335-352

Cibbs, 4., 1987. Jevelopment of extension and mixed-inodo sedimentary basins. In: Coward, M.P. Dewcy, J.F. and Hancoek, P.L. (eds.), Continental extensional teetonics. Geological Society Speci:1 Publication, no. 28, p. 19-33.

Giret, A, and Lameyre, J., 198.5. Inverted alkaline-tholeitic sequences related to lithogherie thickness in the svolution of eontinental rifis and oceanic islands.

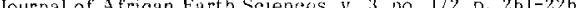

llendriks, F., 1987. Die Fntwicklungsgesehichte des SF-Aryntischen Sediment ty tionsraumes in der Kreide und im Alttertï̈r. Unveröfentlicht Ilabilitationsschrift, Technische Universiteitat Berlin, $167 \mathrm{p}$.

Keen, r.E., 1987. Some important consequences of lithospheric extension. In:

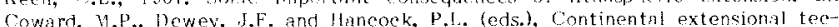
tonics. Geological Socicty Sperial Publication, no. 28, D. 67-73.

klerkx, J. and Rundie, C.C., 1976 . Preliminary $K / A r$ results on different ignoous rock formations from the Jehel Uweinat region (S.F. Libyal. Musée Royal d

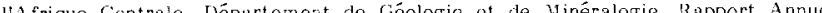
1975 , Tervuren (Beigium), D. 105-111. Klitzech, F., 1970. Die Strukturcesehiehte der Zentralsahara. Geologische Rundt schall, v. 59, no. 1-3, p. $459-527$

Klitzsch, t.. 1981. Lower Palacozoie rocks of liby:, Leypt and Sudan. In: Holland C.11. (ed), C.ll. (ed.), Tower Palaeoroic of the Viddle East,
Klitzseh, F., 1983. Gcologieal researeh in and around Nutia. lipisodes, 1983, no, 3, D. $15-19$

Klitzseh, La and Squyres, H.C. (in press). Now interpretation of the sp-called Nubian Strata in NF A frica. Ameriean Association of Petroleum Geologists Bulletin.

Klitzseh, E. and Wycisk, P., 1987. Geology of the sedimentury basins of Northern Slatan and bordering areas. Berliner geowissenschaftliche Abhandungen, Reihe $A$ Geologie und Paläontologie, v. 75, no. 1, p. 97-136.

Kröncr, A., 1979. Pan African plate tectonies and its reperenssion on the erust of northeast Afrier. Ceologische Rundschru, v. 68, no. 2, p. 565-583.

Liêgeois, J.P., Bertrand, H., Black, R., Caby, R. and Fabre, J., 1983. Permian alkaline undersaturgted and carbonatite provinee, ard rifting glong the Host African craton. Nature, v. 305, mo. 5929, D. $42-43$.

Vekenzie, 1), 1978. Some remarks on the development of sedimentury basins. Finth and Planctary Seicnce Letters, v. 40, no. I, D. 25-32.

Nagv, R.M., Ghuma, Y.A, and Rogers, J.J.W., 1976. A crustal suture and lineament in North Afric. Tectonophysies, v, 31, no. 3-4, p. T67-72.

Park, R.C., 1988. Cicological struetures and moving plates. Blackie and son i,td., Glasgow and Lonton, 337p.

Parsons, B. and Selater, J.S., 1977. An analysis of the variation of ocean floor anthymetry and hagt flow with are, Journal of Cieophysical Research, v. 82, no. 5 , p. $803-827$.

Schandelmcier, H., 1988. Dis Intraplattendeformation Noriost-AfrikasPrakknabische Anlage und Phanerozoische Reaktivierung. Unveroffentlicht Habilitationsschrift, Technische Universiteitht Rerlin, 130p.

Sehandelmeier, II. and Farbyshire, F., 1984. Wetamorphie and ilagmatic events in the Uweinat-Bir Safsaf uptift (Western bescrt/tgypt). Fientogisehe kundschau, v. $73, \mathrm{n} n .2$, D. $819-831$.

Schandelmeier, H., Klitzseh, E., llendriks, r. and wycisk, P., 1987 . Structural do velopment of North-Esst Africa since Prechmbrian times. Berliner Geowissensetaftliche Abbanctungen $A, v, 75$, no. I, p. $5-24$.

Schandelmeier, H., Richter, A. and Harms, U., 1987. Proterozole deformation of the East Saharan Craton in southeast libya, South ligvpt and North Surdan. Tectonophysics, v. 140, no. 2-4, p. 233-245.

Thorweihe, U., 1988. 1): Gs Gundwasser des Nubischen Aquifertystems der Ostsahara, Ilerkunft, Bewegung, Nut zungsmöglichkeiten. Unveroffentlic th Habilitationssehrift, 'T'echnische Universiteität Berlin, II Glp.

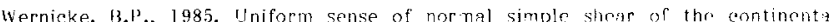
tithosphere. Cantdian Journal of tarth seienees, v, 22, no. 1, p. 108-125.

Wyeisk, P., 1987. Sequential arrangement of eratonic sedimentation siner Silurian

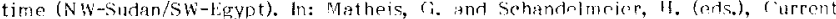

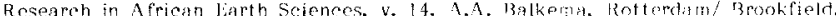
p. $211-216$.

\section{JOURNAL OF PETROLEUM GEOLOGY}

THIS leading UK-based, internationally-read quarterly journal is devoted to the geology of oil and gas, and is now entering its eleventh year of publication. Editorial emphasis is on oilfield regions outside North America: the journal's scope encompasses all petroleum-exploration and development operations, including geochemical an reservoir evaluation.

Between 1978 and 1988 . some 260 original papers were published in the Journal, contributed by authors based in 40 oil-producing countries. During 1989, about 25 further papers will appear, and there will be two thematic issues: "Petroleum geology of the Red Sea and Eastern Africa"; and "Recent developments in the petroleum geology of the People's Republic of China".

\section{SUBSCRIPTIONS}

$£ 88$ for one year (four quarterly issues) - UK only, post free. US $\$ 176$ for all other countries (surface mail: airmail postage extra). Reduced rates for personal subscribers.

PUBI.ISHED BY: Scientific Press Ltd, PO Box 21, Beaconsfield. Bucks HP9 1NS, UK. Phone: (0494 675139. Fax:0494 670155. Telex: 94016686 SSSPG. 